$$
\text { USGS/OFR-- } 97-56
$$

U.S. Department of Interior RECEIVED

U.S. Geological Survey

MAR 201998

OSTI

\title{
STRUCTURAL GEOLOGY OF THE FRENCH PEAK ACCOMMODATION ZONE, NEVADA TEST SITE, SOUTHWESTERN NEVADA
}

by

Mark R. Hudson ${ }^{1}$

Open-File Report 97-56

${ }^{1}$ U.S. Geological Survey, MS 913, Federal Center, Denver, CO 80225

DISTRIBUTION OF THIS DOCUMENT IS UNLIMTED

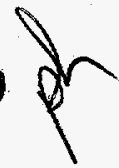

This report is preliminary and has not been reviewed for conformity with U.S. Geological Survey editorial standards. Any use of trade, product, or firm names is for descriptive purposes only and does not imply endorsement by the U.S. Government. 


\section{DISCLAIMER}

This report was prepared as an account of work sponsored by an agency of the United States Government. Neither the United States Government nor any agency thereof, nor any of their employees, makes any warranty, express or implied, or assumes any legal liability or responsibility for the accuracy, completeness, or usefulness of any information, apparatus, product, or process disclosed, or represents that its use would not infringe privately owned rights. Reference herein to any specific commercial product, process, or service by trade name, trademark, manufacturer, or otherwise does not necessarily constitute or imply its endorsement, recommendation, or favoring by the United States Government or any agency thereof. The views and opinions of authors expressed herein do not necessarily state or reflect those of the United States Government or.any agency thereof. 


\section{DISCLAIMER}

Portions of this document may be illegible electronic image products. Images are produced from the best available original document. 


\section{Abstract}

The French Peak accommodation zone (FPAZ) forms an east-trending bedrock structural high in the Nevada Test Site region of southwestern Nevada that formed during Cenozoic Basin and Range extension. The zone separates areas of opposing directions of tilt and downthrow on faults in the Yucca Flat and Frenchman Flat areas. On the eastern end of the FPAZ, the Puddle Peak segment of the zone is dominated by a combination of north-striking normal faults and northeast- to east-northeast-striking sinistral faults that merge and splay in a complex pattern. Farther west in the FPAZ, the CP segment is dominated by north-striking, east-dipping normal faults. Strata in the Yucca Flat domain north of the zone dip west whereas those in the Frenchman Flat domain south of the zone dip east to southeast. Strata within the FPAZ mostly dip south but locally north. Strata mostly strike parallel to and dip opposite to surrounding faults, but where faults of mixed strike are present within the FPAZ, strata commonly have strikes that are intermediate between those of the faults. Paleomagnetic data show that rocks within the accommodation zone adjacent to Yucca Flat were not strongly affected by vertical-axis rotation and thus that the transverse strikes of fault and strata formed near their present orientation. Both normal- and oblique strike-slip faulting in the FPAZ largely occurred under a normal-fault stress regime, with least principal stress oriented west-northwest. The normal and sinistral faults in the Puddle Peak segment transfers extension between the Plutonium Valley normal fault zone and the Cane Spring sinistral fault. Recognition of sinistral shear across the Puddle Peak segment allows the Frenchman Flat basin to be interpreted as an asymmetric pull-apart basin developed between the FPAZ and a zone of east-northeast-striking faults to the south that include the Rock Valley fault.

The FPAZ has the potential to influence ground-water flow in the region in several ways. Fracture density and thus probably fracture conductivity is high within the FPAZ due to the abundant fault splays present. Moreover, fractures oriented transversely to the general southward flow of ground water through Yucca Flat area are significant and have potential to laterally divert ground water. Finally, the FPAZ forms a faulted structural high whose northern and southern flanks may permit intermixing of ground waters from different aquifer levels, namely the lower carbonate, welded tuff, and alluvial aquifers.

\section{Introduction}

Accommodation zones (Bosworth, 1985; Faulds and others, 1990) have been recognized in extensional terranes throughout the world as zones that separate areas of contrasting structural style and asymmetry of extensional strain. Accommodation zones are commonly oriented transversely to the dominant strike of faults and stratal attitudes within extensional provinces. Accommodation zones have received much recent study both because of the insights that they give to the nature of extensional deformation (e.g., Faulds and others, 1990) and because of their potential influence on resources such as ground water, hydrocarbons, and mineral deposits (Morley and others, 1990; Nelson and others, 1992; Rowley, in press) and seismic hazards (Fonseca, 1988). 
Accommodation zones have long been recognized within the Basin and Range province of western North America (e.g., Davis and Burchfiel, 1973; Stewart, 1980). Within the Nevada Test Site area, the west-trending French Peak accommodation zone (FPAZ), here named after the flat-topped peak at the southeast margin of Yucca Flat (Fig. 1), corresponds to a structural high of Miocene volcanic bedrock separating the Cenozoic Yucca Flat structural basin to the north from the Frenchman Flat and CP structural basins and intervening Massachusetts Mountain to the south. These areas separated by the FPAZ comprise structural domains having different directions of tilt and downthrow on extensional faults. In the Yucca Flat structural domain, rocks are extended dominantly along north-striking normal faults with down-to-the-east throw. The rocks between these faults dip dominantly west. The east-dipping Carpetbag-Yucca fault normal fault zone is a key feature in the structural evolution of the Yucca Flat domain inasmuch as it forms the western boundary of the deep half-graben that underlies the eastern two thirds of Yucca Flat. In the Frenchman Flat structural domain south of the FPAZ, rocks are extended along north- to east-northeast-striking normal and sinistral faults having dominant downto-the-northwest throw. The rocks between these faults dip dominantly east to southeast. The northeast-striking sinistral Cane Spring fault is a key feature within the Frenchman Flat structural domain that, based on gravity and aeromagnetic anomalies, can be traced northeast across CP Basin to a termination at the 6-3C Pass at the southeastern margin of Yucca Flat (Carr, 1984).

Margins of the FPAZ are indistinct, but the zone that encompasses transversely oriented faults and stratal attitudes is roughly $5 \mathrm{~km}$ wide (Fig. 1). The FPAZ can be traced westward beyond Yucca Flat at least across the southern margin of Mid Valley. This report is restricted to parts of the zone adjacent to Yucca Flat. The French Peak accommodation zone is further divided into two segments at 6-3C Pass. The eastern Puddle Peak segment has different structural character than the western CP segment. This report summarizes observations on the structural geology of this accommodation zone and briefly speculates on its potential relevance to regional ground-water flow.

\section{Stratigraphy}

This study was restricted to structural features developed within Miocene volcanic rocks of the southwestern Nevada volcanic field (Byers and others, 1989), excluding any features related to older Mesozoic phases of deformation in the region. Volcanic units exposed at the surface within the FPAZ and adjacent to Yucca Flat include, in ascending stratigraphic order: (1) an undivided sequence of nonwelded to poorly welded ash-flow and bedded tuffs that are largely related to the 13.25-Ma Bullfrog Tuff but that also contain older deposits such as the Grouse Canyon Tuff, tuff of Yucca Flat, and 15.25-Ma Redrock Valley Tuff (locally welded); (2) bedded tuffs and lava flows of the 12.9-Ma Wabmonie Formation and thin overlying beds of the Calico Hills Formation; (3) the 12.8Ma Topopah Spring Tuff, (4) the 11.6-Ma Rainier Mesa Tuff; and (5) the 11.45-Ma Ammonia Tanks Tuff. Stratigraphic usage and isotopic dates cited in this report follow Sawyer and others (1994). The stratigraphic base of the Ammonia Tanks Tuff in this study (Plate 1) was mapped higher than by Hinrichs and McKay (1965). Reverse 


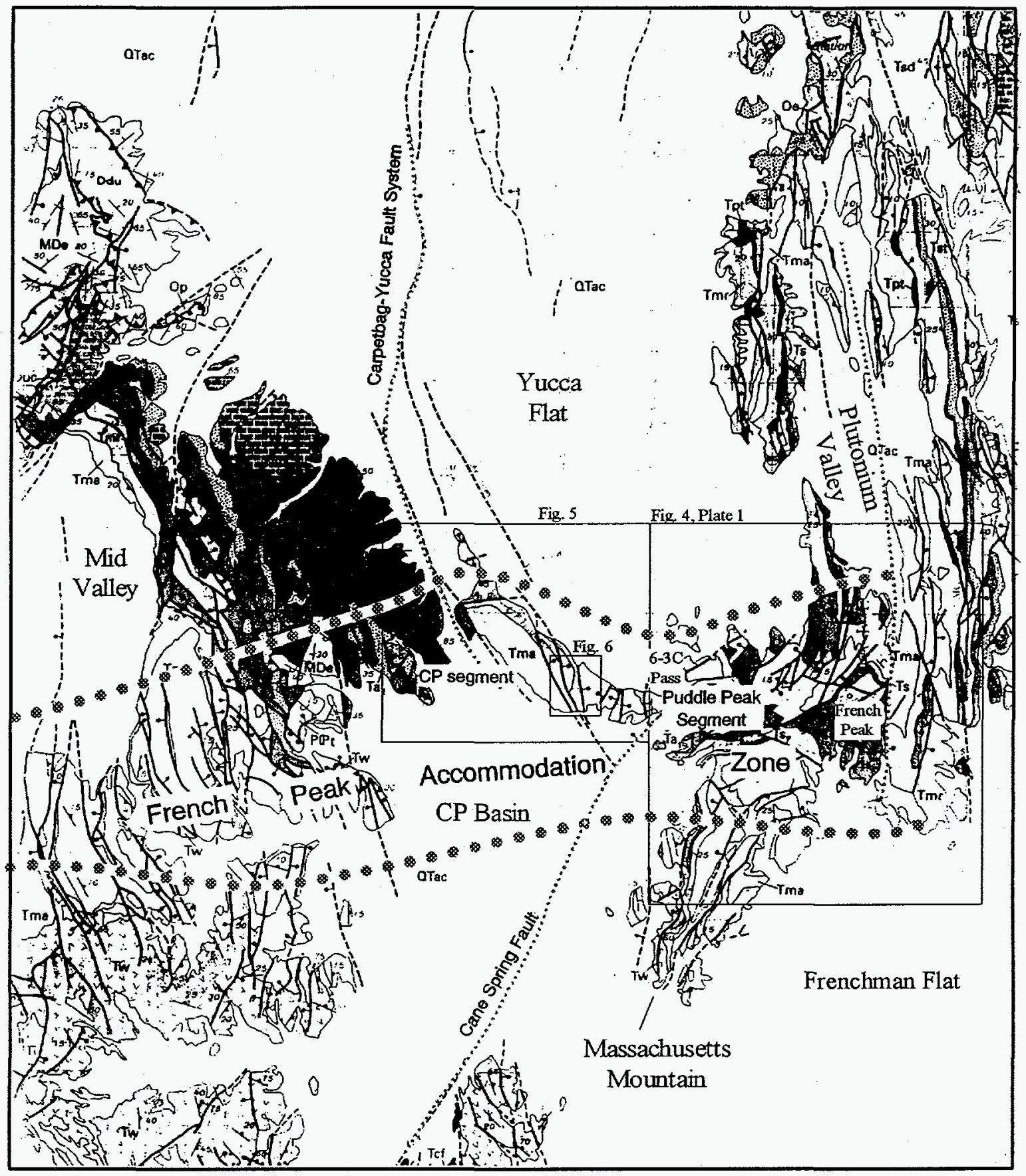

Figure 1. Generalized geologic map of part of the Nevada Test Site in southwestern Nevada (from Sawyer and others, 1995) showing location of the French Peak accommodation zone and its Puddle Peak and CP segments. 
remanent magnetizations from (Hudson, 1992), and field observations of, the lowest ledge-forming part of the Ammonia Tanks Tuff of Hinrichs and McKay (1965) show that this tuff interval is an upper vapor-phase zone of the Rainier Mesa Tuff.

\section{Methods of study}

For this work the available 1:24,000 scale geologic maps encompassing the FPAZ area (Hinrichs and McKay, 1965; McKeown and others, 1976) were examined and locally revised. New mapping (1:12,000 scale) was principally conducted in the Puddle Peak segment to better determine the extent and interconnection of faults (Plate 1), although the map for parts of the CP segment was also revised. Additional measurements of stratal tilt were determined from attitudes of compaction foliation in ash-flow tuffs or from beds in bedded tuffs to better understand the change of dips within the FPAZ. Faults having both map-scale and smaller offsets were examined throughout the region to determine their orientation, slip direction, and slip sense. Paleomagnetic data from the Miocene volcanic rocks in the region of the FPAZ (Hudson, 1992; Hudson and others, 1994; Hudson, unpublished data) were used to constrain the stratigraphy and effects of rotational strain within the accommodation zone.

\section{Faulting}

The nature of faulting within the FPAZ is key to understanding its structural development. Several characteristics of faults were investigated during this study.

\section{Fault kinematics}

To better understand the kinematics of faulting within the accommodation zone, numerous measurements of fault attitudes, slip directions, and slip senses were recorded. Fault data were collected principally in the Puddle Peak segment of the FPAZ and the Massachusetts Mountain area to the south, but faults were also recorded at several sites within the CP segment to the west. A total of 384 fault planes were examined and slip striae were observed for 341 faults. The sense of slip was determined for 322 faults, either directly from offset of preexisting markers or from small-scale asymmetric features of the fault planes (Petit, 1987). Most faults of this population have small offsets $(<1 \mathrm{~m})$ but in many places such fault data were gathered on or adjacent to mappable faults and are considered to reflect their kinematics.

The majority of faults strike between north-northeast and east-northeast and dip from $50^{\circ}$ to $90^{\circ}$ northwest or southeast (Fig 2A). The fault strikes, however, can be further divided into sets if the faults are sorted according to their dominant slip sense. Faults whose slip is dominantly normal, having striae rakes $>45^{\circ}$, are the most abundant group $(\mathrm{n}=221)$ of the fault population (Fig. $2 \mathrm{~B})$. These normal faults mostly strike north-northeast and dip from $50^{\circ}$ to $80^{\circ}$ either west-northwest or east-southeast. In addition to normal slip, most of these faults also have a sinistral strike-slip component of 

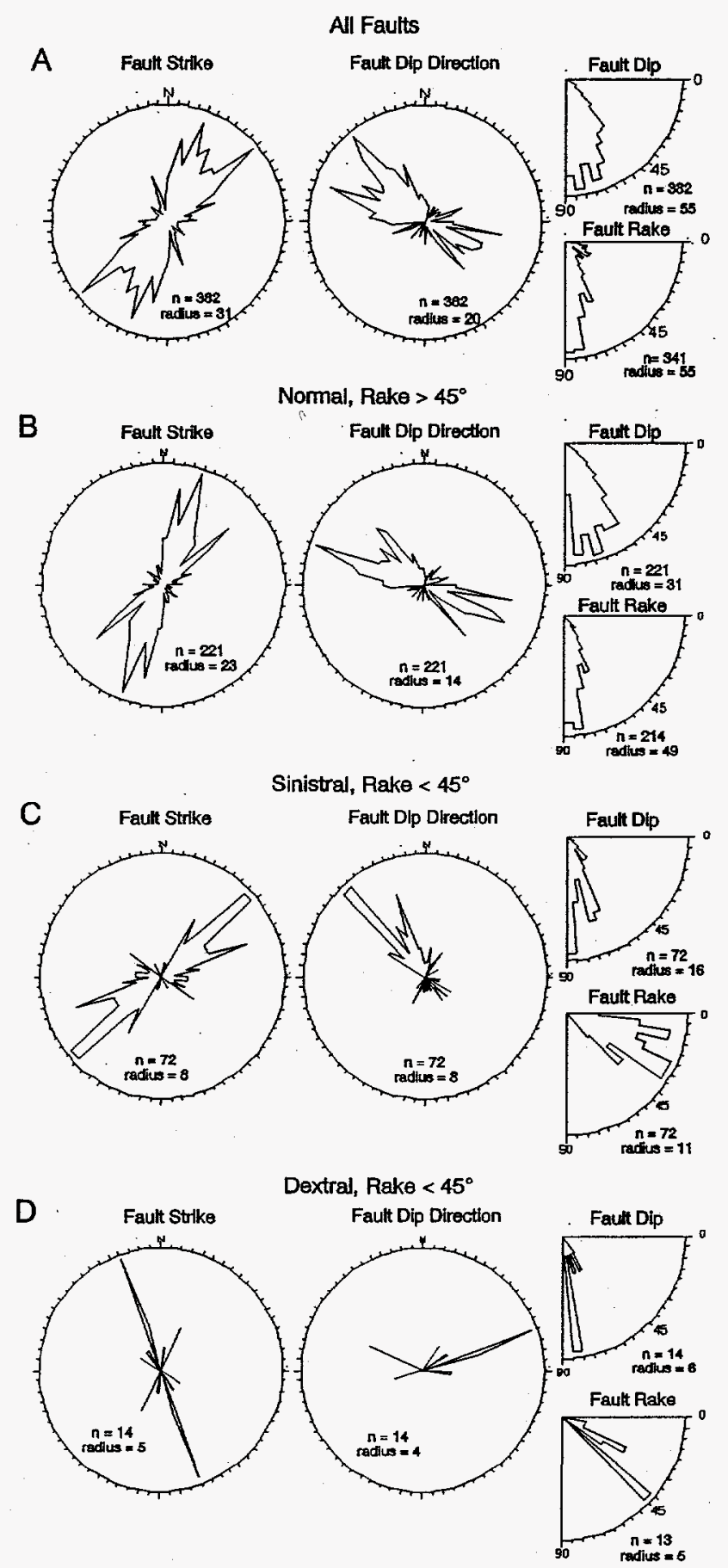

Figure 2. Rose diagrams depicting characteristics of faults examined within the study area of the French Peak accommodation zone and Massachusetts Mountain. (A) All faults of population. (B) Subset of dominantly normal-slip faults having rakes of fault slip striations $>45^{\circ}$. (C) Subset of dominantly strike-slip faults (rake of fault striae $<45^{\circ}$ ) having sinistral sense. (D) Subset of dominantly strike-slip faults (rake of fault striae $<$ $45^{\circ}$ ) having dextral sense. 
slip. Dominantly strike-slip faults, having striae rakes $<45^{\circ}$, are mostly sinistral $(n=72)$. These sinistral faults (Fig. 2C) typically strike between northeast and east-northeast and $\operatorname{dip} 70^{\circ}-90^{\circ}$ northwest. Although their dominant slip component is sinistral, most also accommodate a component of normal slip as illustrated by their rake maxima at $30^{\circ}$ rather than zero. Dextral faults (Fig. 2D) are subordinate in the fault population $(n=14)$ and they predominantly have northwest strikes.

Subsets of the fault population were also sorted by location to illustrate the character of faults in different parts of the study area (Fig. 3). Northeast-striking normal oblique sinistral faults are principally found in the Puddle Peak segment of the FPAZ. In contrast, faults recorded in the CP segment are mostly normal faults. Faults recorded in the Massachusetts Mountain area south of the FPAZ are dominantly west-northwest dipping normal faults. These three fault groups were analyzed using the method of Angelier (1992) to estimate paleostress tensors that best fit the majority of data from each of these three regions (Table 1). A normal-faulting tensor (with subvertical and subhorizontal greatest and least principal stress axes, respectively) having a westnorthwest trending azimuth of least-principal stress was derived that fit at least 70 percent of the faults in each group. It is of note that this analysis indicates that activity of oblique sinistral faults within the Puddle Peak segment did not require a change to a stress-field having a typical strike-slip faulting tensor (with subhorizontal greatest and least principal stress axes).

Table 1. Paleostress analytical results from fault slip inversions

$\left[\mathrm{n} / \mathrm{n}_{\mathrm{t}}\right.$, number of fault data used in inversion/total number of fault data; $\sigma_{1}, \sigma_{2}, \sigma_{3}$, greatest, intermediate, and least principal stress axis, respectively; $\left.\phi,\left(\sigma_{2}-\sigma_{3}\right) /\left(\sigma_{1}-\sigma_{2}\right)\right]$

\begin{tabular}{lcccccccc}
\hline \multicolumn{1}{c}{ Area } & $\mathrm{n} / \mathrm{n}_{\mathrm{t}}$ & \multicolumn{2}{c}{$\sigma^{\sigma_{1}}$} & \multicolumn{2}{c}{$\sigma$} & \multicolumn{2}{c}{$\sigma_{3}$} & $\phi$ \\
\hline $\begin{array}{l}\text { Puddle Peak } \\
\text { segment }\end{array}$ & $90 / 129$ & 240 & 84 & 20 & 5 & 110 & 4 & 0.50 \\
CP segment & $40 / 54$ & 229 & 81 & 14 & 8 & 104 & 5 & 0.30 \\
$\begin{array}{l}\text { Massachusetts } \\
\begin{array}{l}\text { Mountain } \\
\hline\end{array}\end{array}$ & $39 / 56$ & 187 & 87 & 22 & 3 & 292 & 1 & 0.37 \\
\hline
\end{tabular}

\section{Depth variation of fault-rock deformation}

A systematic variation in the style of rock deformation within and adjacent to faults, related to both stratigraphic level and lithology, was noted during the course of this study. Most faults observed at or below the stratigraphic level of the Topopah Spring Tuff occur as discrete shear planes. These faults are typically striated and contain thin zones $(<3 \mathrm{~cm})$ of fine-grained gouge. The character of fault deformation is more variable 

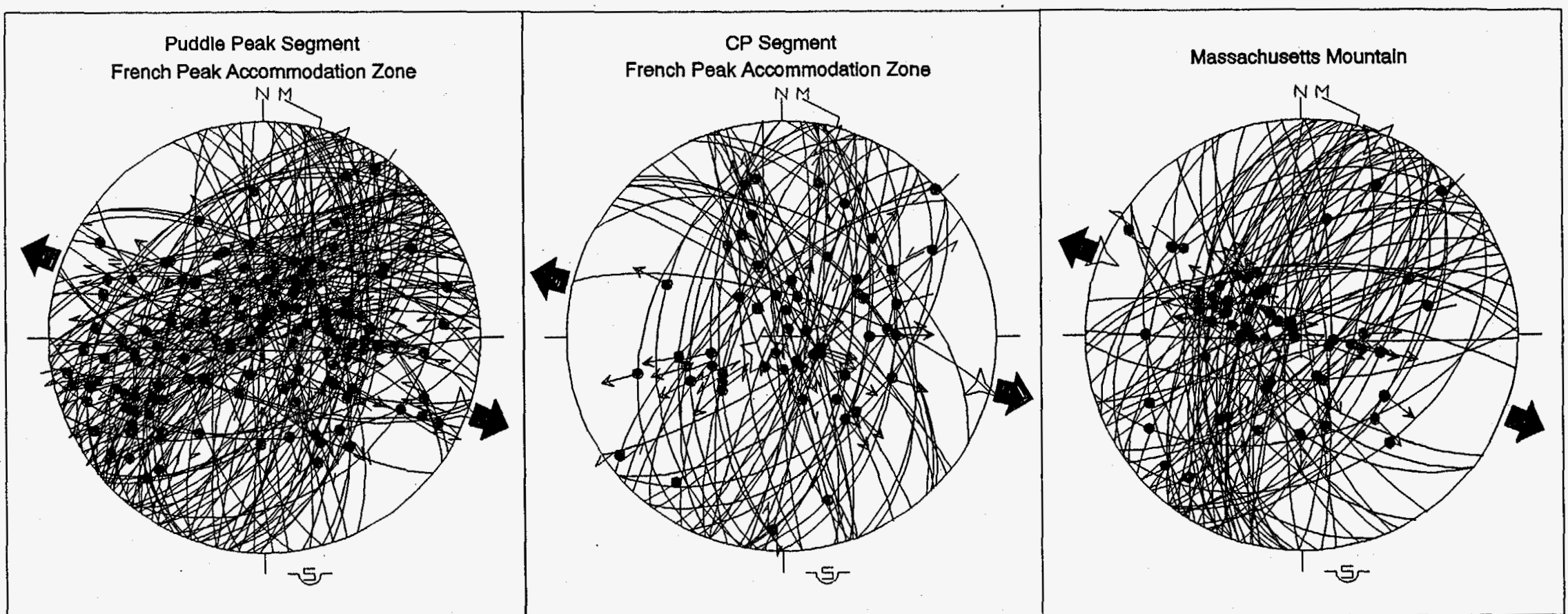

Figure 3. Equal-area projections of fault data from the Puddle Peak and CP segments of the FPAZ and from the Massachusetts Mountain area. Fault planes are shown as arcs and slip striae are shown as dots. Arrows on dots indicate slip sense. Stars with three, four, and five points indicate axes of greatest, intermediate, and least principle stress as estimated for the fault subsets using the methods of Angelier (1990). Large black arrows indicate azimuth of least principle stress. Stress tensors fit 70 percent or more of each fault subset. 
at higher stratigraphic levels, within the Rainier Mesa and Ammonia Tanks Tuffs. Faults in non-welded and poorly welded zones of these upper units also formed discrete shear planes. In contrast, faults within densely welded zones of these units typically formed planar zones of breccia, 0.5-2 m wide and composed of angular wallrock fragments that generally show little preferential orientation. Slip directions could rarely be determined for such brecciated faults. Brecciated faults are most common in the Ammonia Tanks Tuff, probably due to the low confining pressure that existed during deformation within this topmost unit. This change of fault character from discrete shear planes to breccia zones is common in the near-surface environment (Sibson, 1977)

\section{Map-scale faults}

Mapped faults in the Puddle Peak segment of the FPAZ (Plate 1, Fig. 4A) show characteristics of both the Yucca Flat and Frenchman Flat structural domains. North- to north-northeast-striking faults with down-to-the-west throw in Massachusetts Mountain curve to east-northeast strikes with down-to-the-north throw as they enter the accommodation zone from the south from the Frenchman Flat domain. Because of this consistent relation, the down-to-the-north faults are associated with the Frenchman Flat domain in the Puddle Peak segment and shown as solid lines on Figure 4A. Conversely, faults having down-to-the-east to down-to-the-south throw are associated with the Yucca Flat structural domain and shown as dashed lines.

A fundamental characteristic of the faulting within the Puddle Peak segment is abundant splaying and merging of faults of different strikes (Plate 1, Fig. 4A). The eastdipping Plutonium Valley normal fault zone forms an eastward boundary beyond which few of the northeast- to east-northeast-striking faults extend. Coincident with a southward loss of throw, numerous northeast-striking faults splay from the Plutonium Valley fault zone at its southern end (Plate 1). Northeast- to east-striking sinistral faults are much less abundant west of the 6-3C Pass (Fig. 5); most are interpreted to merge with the buried projection of the Cane Spring fault.

Mapped faults within the CP segment (Fig. 5) are predominantly north-northeast to north-northwest striking, east dipping normal faults associated with the Yucca Flat domain. Several west-striking, down-to-the-north faults are exposed on the northern side of the CP Hogback. These transverse faults merge with north-striking, east-dipping normal faults to collectively downdrop Ammonia Tanks and Rainier Mesa Tuffs in small blocks on the northeast flank of the large intact fault block that comprises most of CP Hogback. McKeown and others (1976) mapped these small blocks as landslides, but they are bounded by steeply dipping faults and tuffs within them have foliations that consistently dip west (Fig. 5), concordant with the regional structural pattern. In a similar manner, the transverse faults exposed at the northwest end of CP Hogback probably merge with a buried strand of the Carpetbag fault zone to the west. If these west-striking transverse faults were active in a normal faulting stress regime in which least-principle stress was oriented west-northwest (Fig. 3), they probably accommodated some 


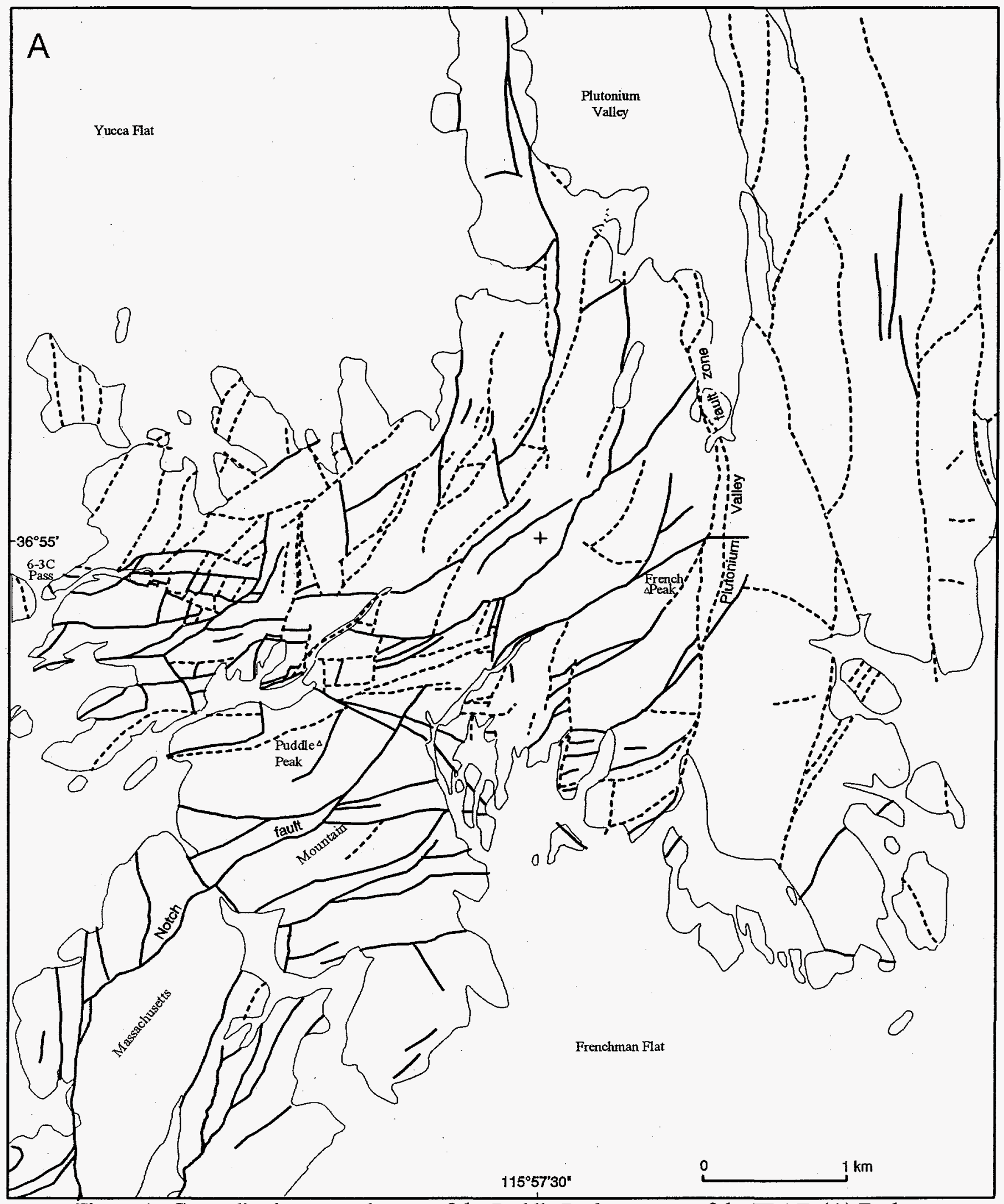

Figure 4. Generalized structural maps of the Puddle Peak segment of the FPAZ. (A) Fault traces. Solid lines represent faults that have downthrow to the west or north, whereas dashed lines represent faults that have downthrow to the east or south. (B) Attitudes of compaction foliation and bedding. Dip tracts highlight areas of different dominant dip directions: I - west dipping, II - east dipping, III - south dipping, IV - north dipping. (C) Combination of fault and attitude data. 


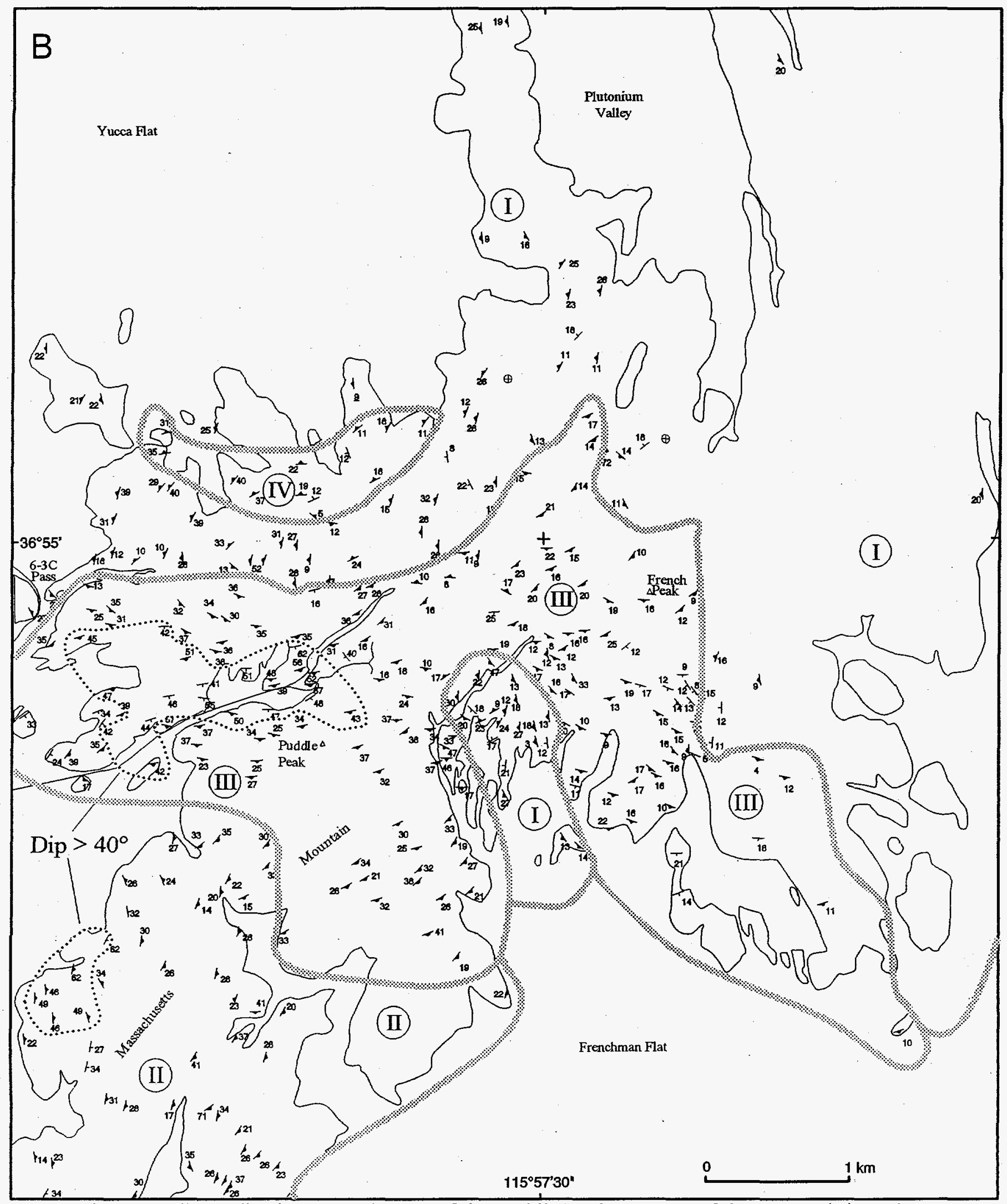

Figure 4. Generalized structural maps of the Puddle Peak segment of the FPAZ. (A) Fault traces. Solid lines represent faults that have downthrow to the west or north, whereas dashed lines represent faults that have downthrow to the east or south. (B) Attitudes of compaction foliation and bedding. Dip tracts highlight areas of different dominant dip directions: I - west dipping, II - east dipping, WI - south dipping, IV - north dipping. (C) Combination of fault and attitude data. 


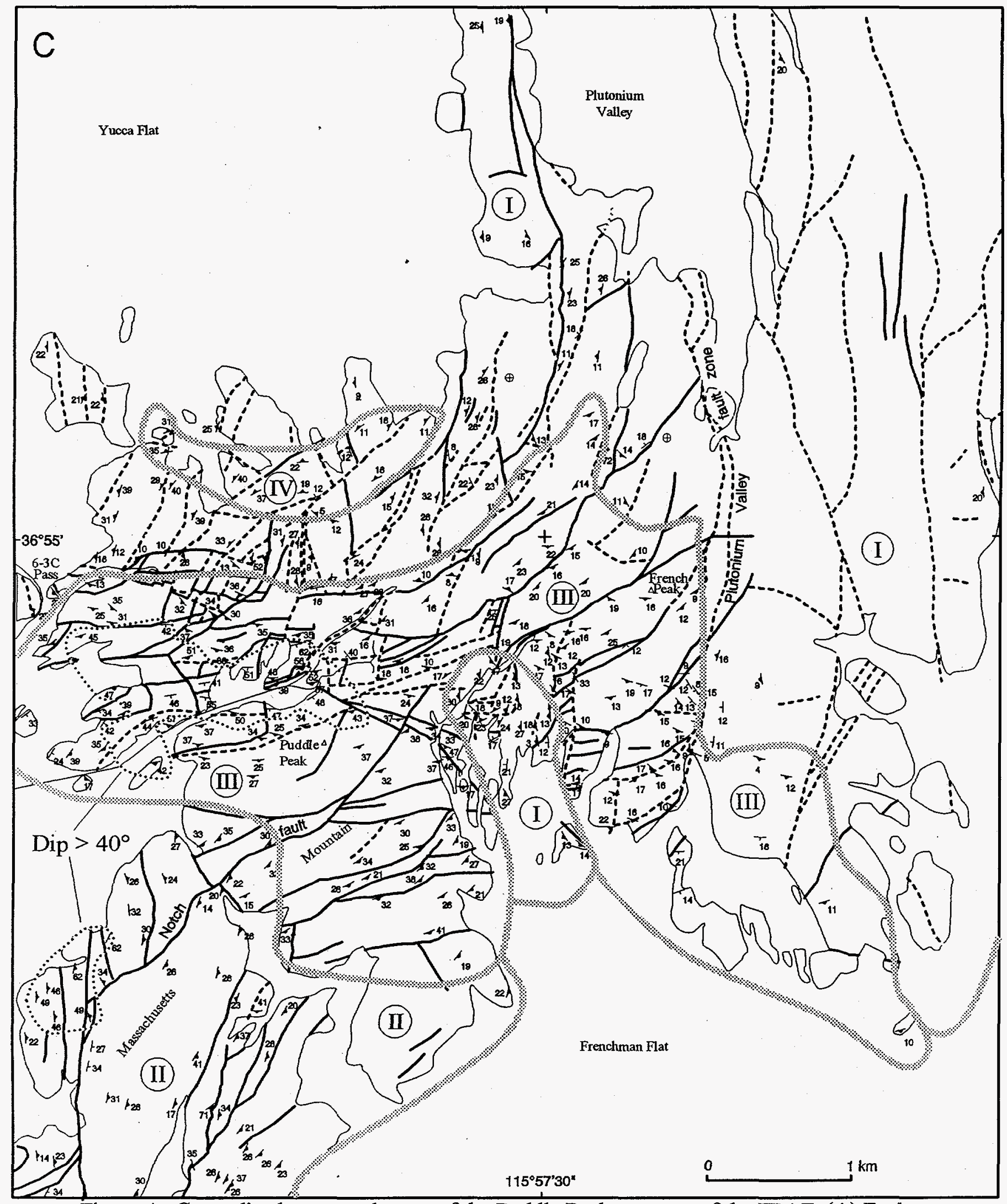

Figure 4. Generalized structural maps of the Puddle Peak segment of the FPAZ. (A) Fault traces. Solid lines represent faults that have downthrow to the west or north, whereas dashed lines represent faults that have downthrow to the east or south. (B) Attitudes of compaction foliation and bedding. Dip tracts highlight areas of different dominant dip directions: I - west dipping, II - east dipping, III - south dipping, IV - north dipping. (C) Combination of fault and attitude data. 


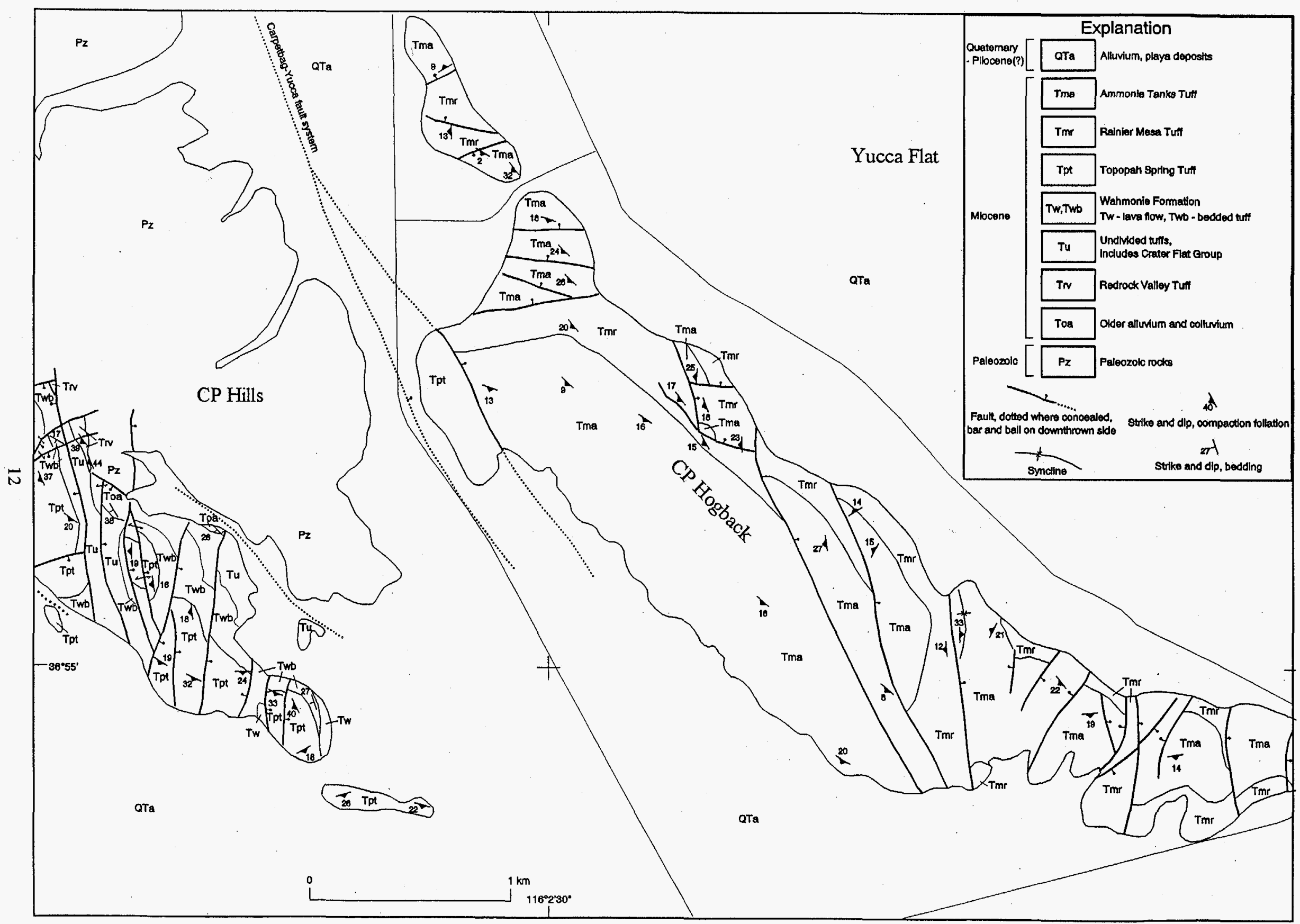

Figure 5. Geologic map of the western CP segment of the FPAZ. 
component of sinistral strike-slip displacement. Few striated fault surfaces, however, were found to directly confirm this inference.

\section{Stratal dip patterns}

The change of stratal dip directions is a defining characteristic of FPAZ. This change from west dips in the Yucca Flat domain to east to southeast dips in the Frenchman Flat domain is fully exposed in the Puddle Peak segment. Four dip tracts encompassing relatively constant dip directions were highlighted within the Puddle Peak segment (Fig. 4B) to facilitate their discussion. The changes in dip directions across some tract boundaries are gradational and thus the boundaries are somewhat subjective. Tract I contains west-dipping strata characteristic of the Yucca Flat structural domain. Tract II contains east-dipping strata characteristic of the Frenchman Flat structural domain. Tracts III and IV encompass transversely striking rocks that dip south and north, respectively. South dipping rocks of tract III are dominant in the FPAZ and partly intervene between tracts I and II. The east-west distribution of tract III is locally interrupted between Massachusetts Mountain and French Peak by a $1.5-\mathrm{km}$-long north-trending band of tract I west-dipping strata. The presence of this band suggests that the influence of the Yucca Flat structural domain locally extended well beyond the median line of the accommodation zone. Tract IV appears as a small area of north-dipping strata embedded within westdipping strata of tract $\mathbf{I}$.

The change from west- to east-dipping rocks is not exposed in the area of Figure 5 within the CP segment of the FPAZ. Instead, dip directions mostly range between west and south.

No obvious change in amounts of dip accompanies the change of dip directions as rocks enter the FPAZ. The volcanic rocks typically dip between $10^{\circ}$ to $40^{\circ}$ in both the Puddle Peak and CP segments. Only two sizable areas were identified within the study area where the volcanic rocks dip more steeply, between $40^{\circ}$ and $60^{\circ}$ (Fig $4 \mathrm{~B}$, Plate 1). The largest area lies within tract III and is centered on exposures of Wahmonie and Calico Hills Formations in a topographic saddle between Puddle Peak and the East Pass. The second area lies within tract II where the northeast-striking Notch fault merges into more northerly striking faults in low exposures along the west flank of Massachusetts Mountain.

\section{Relation between faulting and tilting}

A common relation observed in extensional terranes worldwide is that strata within fault blocks dip opposite to their bounding normal faults. The development of such stratal dips is commonly linked to movement on arrays of listric or planar, domino-style normal faults that bound hanging-wall fault blocks (Wernicke and Burchfiel, 1982). An alternative model is that the stratal dips develop as flexure in response to the isostatic imbalance caused by faulting (e.g., Buck, 1988). 
A general coordination between faulting and tilting of strata within the FPAZ is reflected by the coincidence of areas of transversely oriented faults and stratal strikes (Fig. 3, Fig.4). Strata consistently dip opposite to faults where faults have uniform strike and sense of throw. An example is the area southeast of Puddle Peak where the tuffs and faults have parallel northeast strikes (Fig. 4C, Plate 1). It is of note that in this area the relation holds even though these faults are dominantly strike-slip. In areas containing faults with mixed strikes, however, the stratal strikes lie between those of the faults. Stratal dips in these areas appear to reflect composite influences from the different faults. The area characterized by generally southwest dips south of French Peak is an example of such a composite effect between the down-to-the-east Plutonium Valley fault zone and the down-to-the-northeast faults that merge with it. That fault blocks within the FPAZ were not fully rigid is shown by broad flexures indicated by a spatial change of stratal attitudes within some individual fault blocks. These broad flexures are probably a response to faults of different strike. Using this line of reasoning, a change from west to south dips at the south end of the fault block east of the Plutonium Valley fault zone can be used to predict the presence of one or more buried, down-to-the-north, transverse faults that lie east of the Plutonium Valley fault zone beneath northern Frenchman Flat.

The coordinated nature of tilting and faulting suggests that faults in the FPAZ probably have both planar and listric geometries (Plate 1). Parallel planar faults are inferred to separate blocks that have been tilted similar amounts whereas listric geometries are invoked for faults that separate more steeply dipping hanging walls from less steeply dipping footwalls. Supportive evidence of listric geometry for some faults are zones of pervasive synthetic microfaulting locally observed in some hanging wall blocks. These microfaults likely act to collapse the hanging wall blocks into the potential void produced by movement on the curved fault surface. This relationship principally was noted in southeastern fault blocks of the Massachusetts Mountain area, although such microfaulting could not be accurately portrayed at the scale of Plate 1 . A result of this closely spaced faulting is that dips of formation boundaries appear lower than the dip of internal foliation within the tuffs because of the successive downdropping of the strata on oppositely dipping faults. Scott (1990) described similar zones in the Yucca Mountain area.

A convex upward curvature is invoked for a sinistral faults within dip tract III along cross-section B-B' (Plate 1) that locally separate the more steeply tilted subregion (Fig 4B) in its footwall from less tilted hanging wall rocks. This pattern of older more steeply dipping rocks faulted against younger less steeply dipping rocks is geometrically similar to that predicted by models of flexure in response to isostatic imbalance caused by isolated faulting (Buck, 1988). Flexure in response to gravity could explain why the stratal dips remain perpendicular to the major east-northeast-striking sinistral faults of this region even though the principal slip direction on these faults is near their strike. It is unclear, however, whether isostatic forces could have driven flexure at the subkilometer spacing between faults in the FPAZ. Anders and others (1993) note that the geometic effects of planar domino and flexural uplift mechanism converge as fault spacing decreases. 
In contrast to patterns described above where downthrown strata dip toward the fault, hanging-wall tuffs adjacent to some faults were draped upward and generally dip away from the fault. Hanging-wall synclines (Fig. 6) developed locally where these two dip patterns intersect. Hanging-wall drape folds principally developed in the Ammonia Tanks Tuff, but the underlying Rainier Mesa Tuff was also affected adjacent to faults that have large stratigraphic throw (A-A', Plate 1). Tuffs within the upturned limbs are typically highly fractured and have foliation attitudes that show great variation. These characteristics suggest that rocks in the upturned limbs were subjected to brittle particulate flow (Borradaile, 1981). Footwall strata were typically little affected by such drape folding. The restriction of hanging-wall drape folds to the upper stratigraphic levels of this sequence of rheologically similar calc-alkaline ash-flow tuffs suggests that low confining pressure and a consequent decrease in fracture strength was a controlling factor in their development. Withjack and others (1990) describe examples of similar forced folds developed above extensional faults in other natural and experimental settings.

\section{Vertical-axis rotation}

In some areas within the Basin and Range, province strike-slip shear strain was at least partly accommodated by rotation of fault blocks about near-vertical axes (e.g., Nelson and Jones, 1987; Rosenbaum and others, 1991; Hudson and others, in press). Paleomagnetic data from Miocene ash-flow tuffs (Hudson, 1992; Hudson and others, 1994; M.R. Hudson, unpub. data) constrain the amount of vertical-axis rotation of fault blocks in and around the FPAZ (Fig. 7A). These data show that vertical-axis rotations are too small to explain the transverse trends of faults in the Puddle Peak segment of the FPAZ by clockwise oroclinal bending, as was initially suggested for this region by Carr $(1975,1984)$. Local rotations of both clockwise and counterclockwise sense, however, are indicated for blocks within the Puddle Peak segment of the FPAZ (Fig. 7B).

Nonetheless, if data from the 20 sites within the Puddle Peak segment are averaged, they suggest only a small overall counterclockwise rotation of $5^{\circ}$ for this region (standard deviation $=18^{\circ}$ ). Similarly, two sites from the large, southwest-dipping block in the CP Hogback record little vertical-axis rotation. These data indicate that (1) vertical-axis rotation did not accommodate much shear strain within the accommodation zone, and (2) transversely oriented faults and stratal dips formed near their present orientation. These generalizations may not apply farther west within the zone, however, because paleomagnetic data (unpublished data, M. R. Hudson) from two sites at the south end of "The Bench" (McKeown and others, 1976) indicate more than $40^{\circ}$ counterclockwise rotation coincident with a change of fault strikes from north to northwest (Fig. 7A).

Although Hudson and others (1994) concluded that vertical-axis rotations are minimal in Massachusetts Mountain, within the FPAZ, and in the western fault-block ridge of the Halfpint Range directly north of the Puddle Peak segment, they noted consistent indications of $10^{\circ}-20^{\circ}$ counterclockwise rotation of north- to north-northwest-striking fault blocks in the southeastern Halfpint Range, east of the Plutonium Valley fault zone. This observation was attributed to a southward fanning and increase in extension among fault blocks in the southern Halfpint Range. 


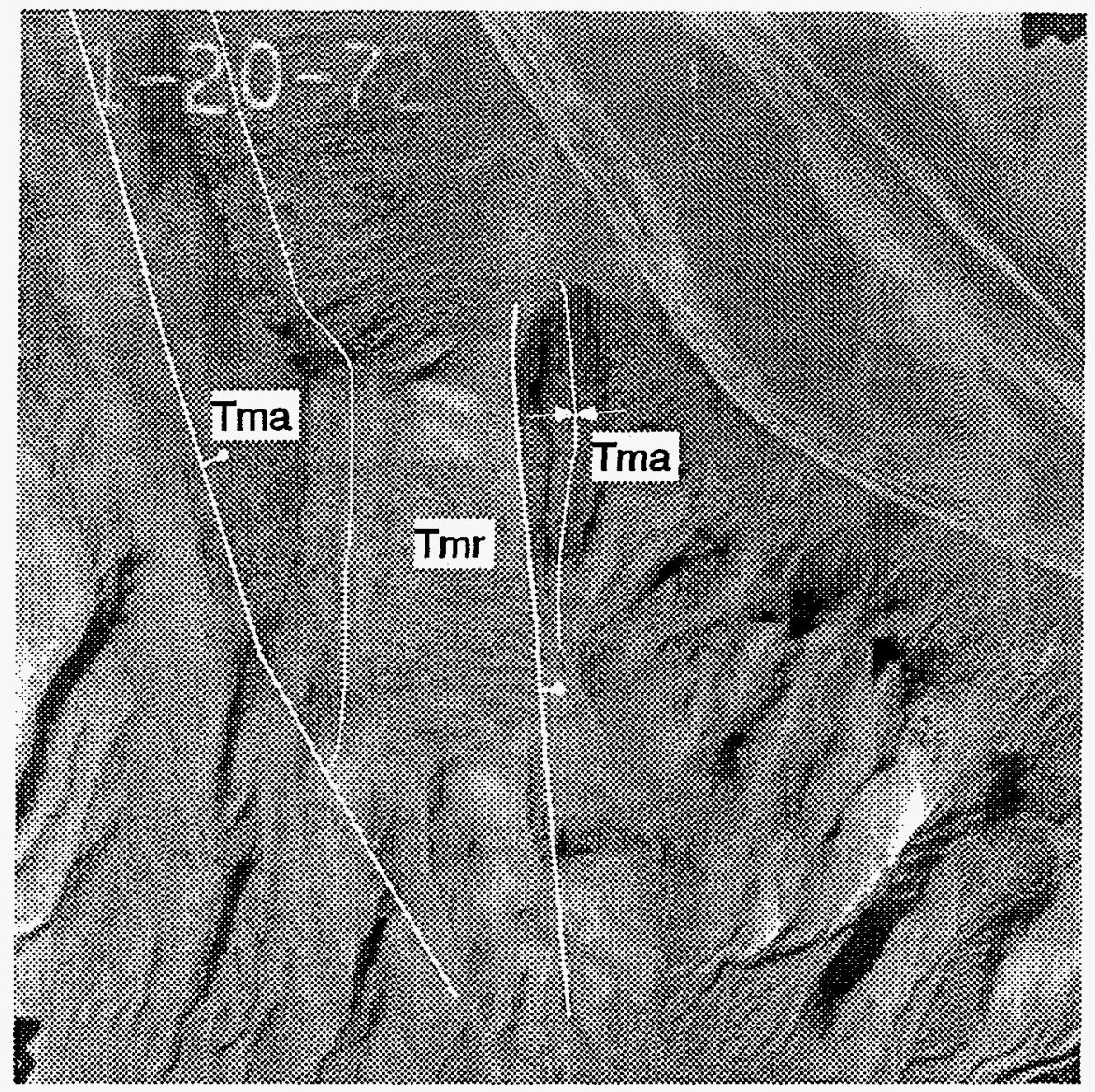

Figure 6. Aerial photograph of part of the southern margin of Yucca Flat, showing local hanging-wall syncline developed from updrape of Ammonia Tanks Tuff adjacent to an east-dipping normal fault. Tma, Ammonia Tanks Tuff; Tmr, Rainier Mesa Tuff 


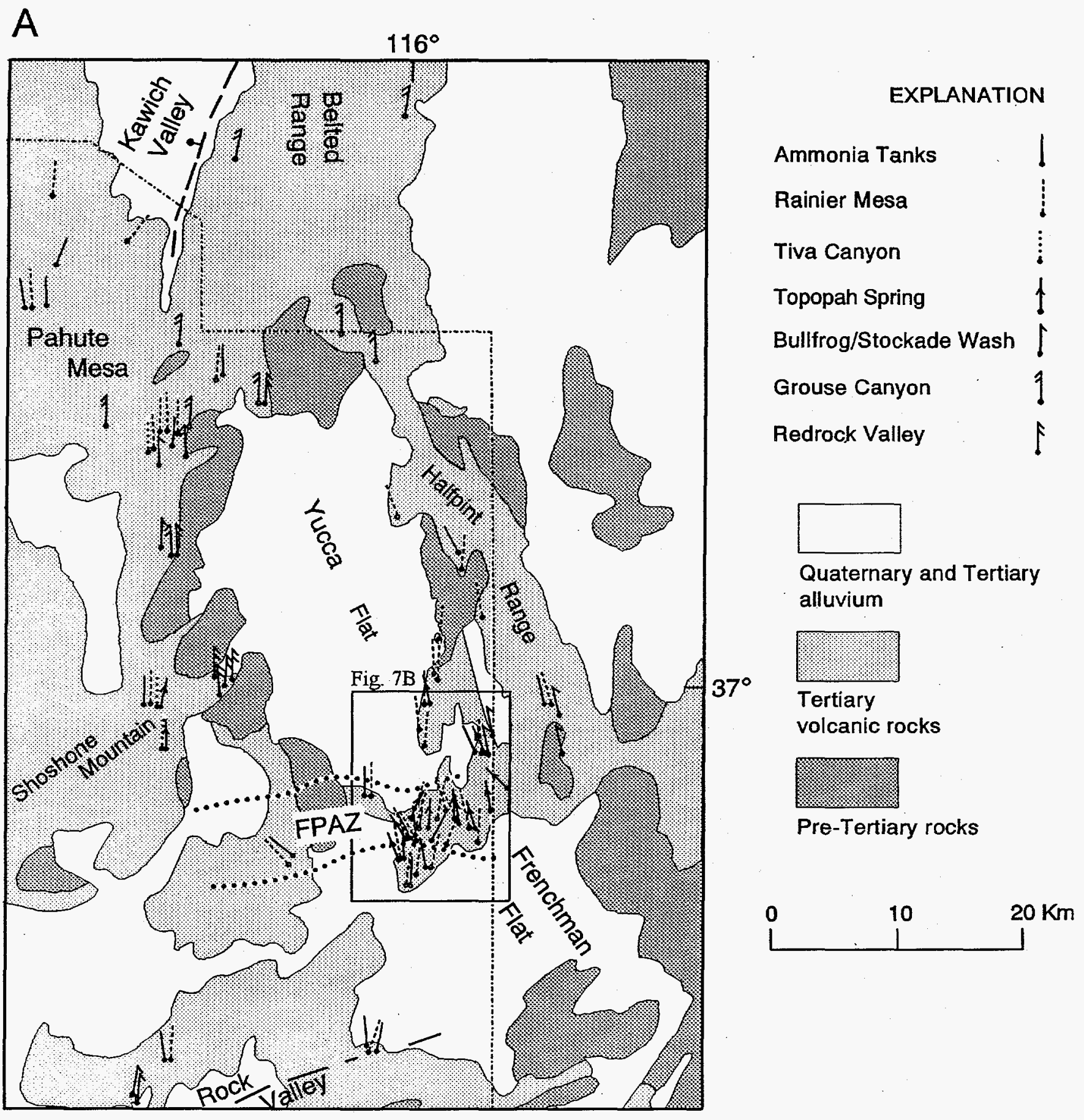

Figure 7. (A) Estimates of relative vertical-axis rotation obtained for paleomagnetic data (Hudson, 1992; Hudson and others, 1994; Hudson, unpub. data) from sites (dots) from ash-flow cooling units in and near the French Peak accommodation zone. Sense and magnitude of rotations are shown by the deflection of the line from north. Rotations are calculated from comparison of tilt-corrected site mean declinations to average reference declinations for individual units given in Hudson (1992) and Hudson and others (1994). (B) More detailed map of vertical-axis rotation estimates from the French PeakMassachusetts Mountain area, modified from Hudson and others (1994). 


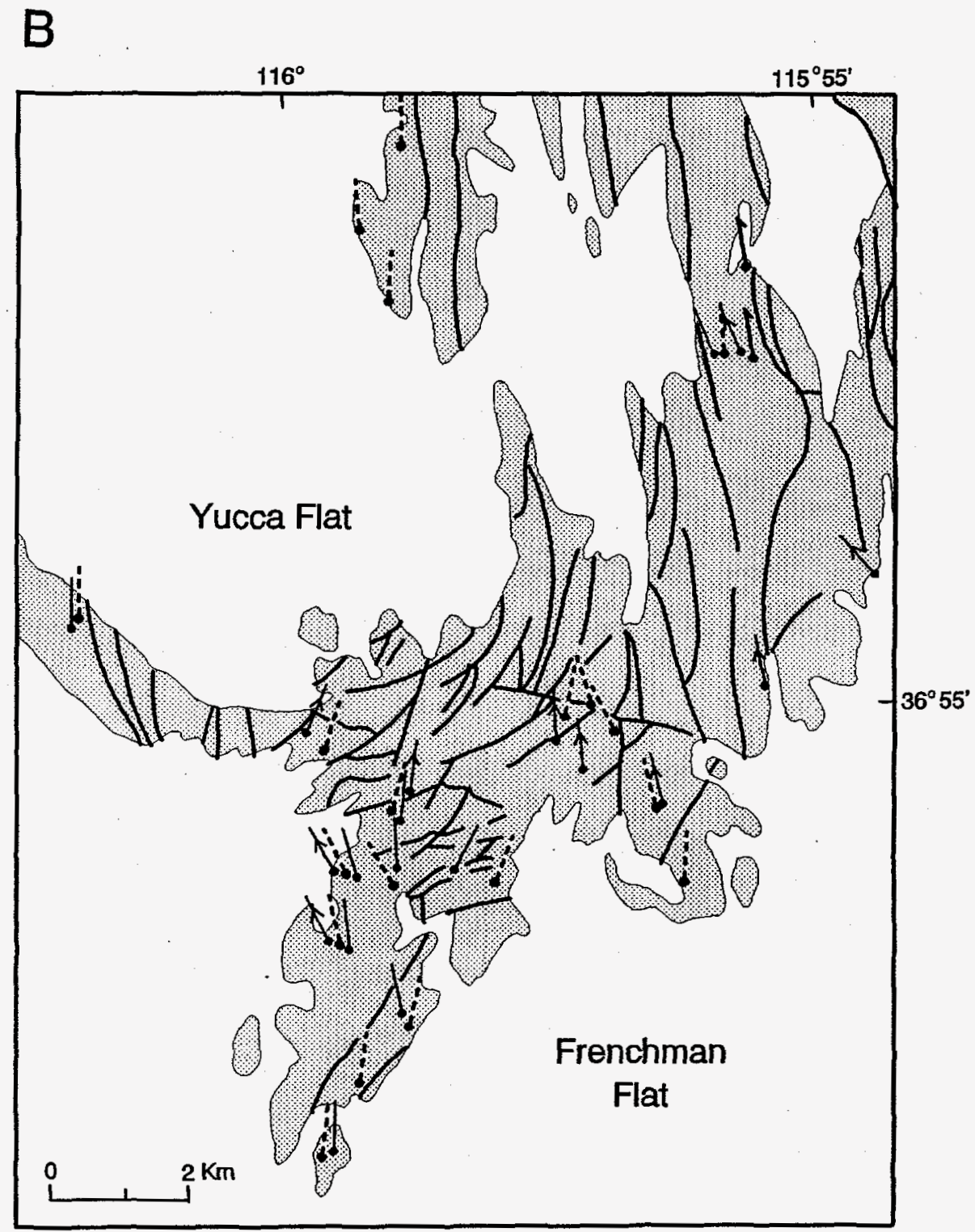

Figure 7. (A) Estimates of relative vertical-axis rotation obtained for paleomagnetic data (Hudson, 1992; Hudson and others, 1994; Hudson, unpub. data) from sites (dots) from ash-flow cooling units in and near the French Peak accommodation zone. Sense and magnitude of rotations are shown by the deflection of the line from north. Rotations are calculated from comparison of tilt-corrected site mean declinations to average reference declinations for individual units given in Hudson (1992) and Hudson and others (1994). (B) More detailed map of vertical-axis rotation estimates from the French PeakMassachusetts Mountain area, modified from Hudson and others (1994). 


\section{Age of deformation}

Most faulting and tilting within the FPAZ is younger than the 11:45 Ma Ammonia Tanks Tuff. No distinct angular unconformities or fault-controlled thickness changes of units indicate that growth faulting was active during deposition of the 13-Ma through 11.45-Ma volcanic strata within the FPAZ. There is a southeastward thickening of the pre-Rainier Mesa bedded tuff unit (Tmra), well displayed in fault blocks south of French Peak (Plate 1), that suggests that a tectonic basin may have developed here between eruptions of the 12.8-Ma Topopah Spring Tuff and the 11.6-Ma Rainier Mesa Tuff. This basin was broad and shallow, however, and thus not clearly linked to the closely spaced faults of the FPAZ. Minor (1995) summarized evidence that faulting within the Halfpint Range initiated before but continued after emplacement of mafic magma centers between 8.5 Ma and 7.6 Ma. Minor (1995) also employed a stress tensor compatibility analysis (Angelier, 1990) to interpret that faulting before and after about 8.5 Ma within the Halfpint Range was active under west-southwest and west-northwest orientations of least principal stress, respectively.

Movements on faults of different strike within the FPAZ were probably broadly contemporaneous because of the mutual abutting relations between the different fault sets. An exception is the 3-km-long, northeast-striking sinistral Notch fault that offsets northwest-striking dextral faults in two places along its length. This relation implies that dextral faults did not remain active as long as sinistral faults within the Puddle Peak segment. Considering the findings of Minor (1995), the west-northwest trend of least principal stress inferred to have been present during most faulting within the FPAZ (Fig. 3) may be evidence that faulting largely occurred after $8.5 \mathrm{Ma}$. There is no clear evidence, however, for Minor's (1995) preceding phase of faulting under a west-southwest principal stress within either the FPAZ or within Massachusetts Mountain to the south. More detailed stress tensor compatibility tests (Angelier, 1990) need to be conducted to eliminate this possibility, but tentatively the absence of evidence for this west-southwest least principal stress suggests that regions within and south of the FPAZ may have undergone a different stress history than the Yucca Flat structural basin and adjacent Halfpint Range. This may reflect a difference in stress histories of the northern Basin and Range and Walker Lane subprovinces (Minor and others, 1997).

\section{Strain transfer in the FPAZ}

A common question concerning the kinematics of accommodation zones in extensional terranes is whether they are sites of significant strike-slip strain. The restriction of abundant northeast- to east-northeast-striking sinistral faults to the Puddle Peak segment suggests that here extension was transferred between the Yucca Flat and Frenchman Flat domains. Strain transfer allowed the Yucca Flat domain to spread westward relative to the Frenchman Flat domain across the eastern FPAZ. Overall sinistral strain in the Puddle Peak segment was partitioned among northeast-striking oblique sinistral faults and north-striking oblique normal faults that individually have small 
offset but that cumulatively may accommodate considerable strain because of their great number. These relations indicate that most sinistral slip on the Cane Spring fault was generated by extension transferred through the Puddle Peak segment.

It is less clear whether significant strike-slip strain transfer is accommodated farther west in the FPAZ, within the CP segment. Although transversely oriented faults splay from the dominantly east-dipping normal faults in the CP segment, they are less abundant and their slip characteristics are more poorly documented than for the Puddle Peak segment. Nonetheless, there is no clear interfingering of oppositely dipping northsouth normal faults as is typical of "twist zones" (Colletta and others, 1988; Faulds and others, 1990) that are thought to accommodate little cumulative strike-slip strain transfer.

The onset of consistent counterclockwise vertical-axis rotation in the southeastern Halfpint Range (Fig. 7A) begins just east of the Plutonium Valley fault zone where most northeast-striking sinistral faults of the Puddle Peak segment terminate to the west. This coincidence suggests that sinistral strain transfer continues further eastward into the southeastern Halfpint Range but that the mechanism of strain transfer here changes to rotation of fault blocks (e.g., Sengor, 1987; Hudson and others, in press). As such, concentrated shear in the Puddle Peak segment of the FPAZ gives way to a broader zone of sinistral shear in the southeastern Halfpint Range (Fig. 8). A similar partitioning between strain transfer accommodated by block rotation versus slip on discrete strike-slip faults has been interpreted by Hudson and others (in press) near the Pahranagat shear zone to the east. Hudson and others (in press) also speculated that there may be a link between the zone of sinistral shear associated with the Pahranagat shear zone and that described here in the southeastern Halfpint Range and French Peak area.

The recognition that the Puddle Peak segment is a zone of sinistral strain transfer also offers insight into the origin of the Frenchman Flat structural basin (Fig. 8). Westdipping normal faults that offset east-tilted rocks within and adjacent to Frenchman Flat are bounded by zones of sinistral shear on both the north (Puddle Peak segment and Cane Spring fault) and the south (Rock Valley and parallel faults). In this context the Frenchman Flat basin can be viewed as an asymmetric half-graben that formed as a pullapart basin between these two overlapping zones of sinistral shear.

\section{Comparison and contrasts with other accommodation zones}

In many respects, the FPAZ is similar to accommodation zones described elsewhere in the world, but it also has some characteristics that are relatively uncommon. Faulds and Varga (in press) reviewed characteristics of accommodation zones that have been studied in many extensional provinces of the world, providing a useful basis of comparison for the FPAZ. Like the FPAZ, nearly all accommodation zones form structural highs relative to adjoining structural domains due to the loss of throw on faults that enter the accommodation zones. As a consequence, accommodation zones commonly separate depositional basins; Yucca Flat and Frenchman Flat in the case of the FPAZ. 


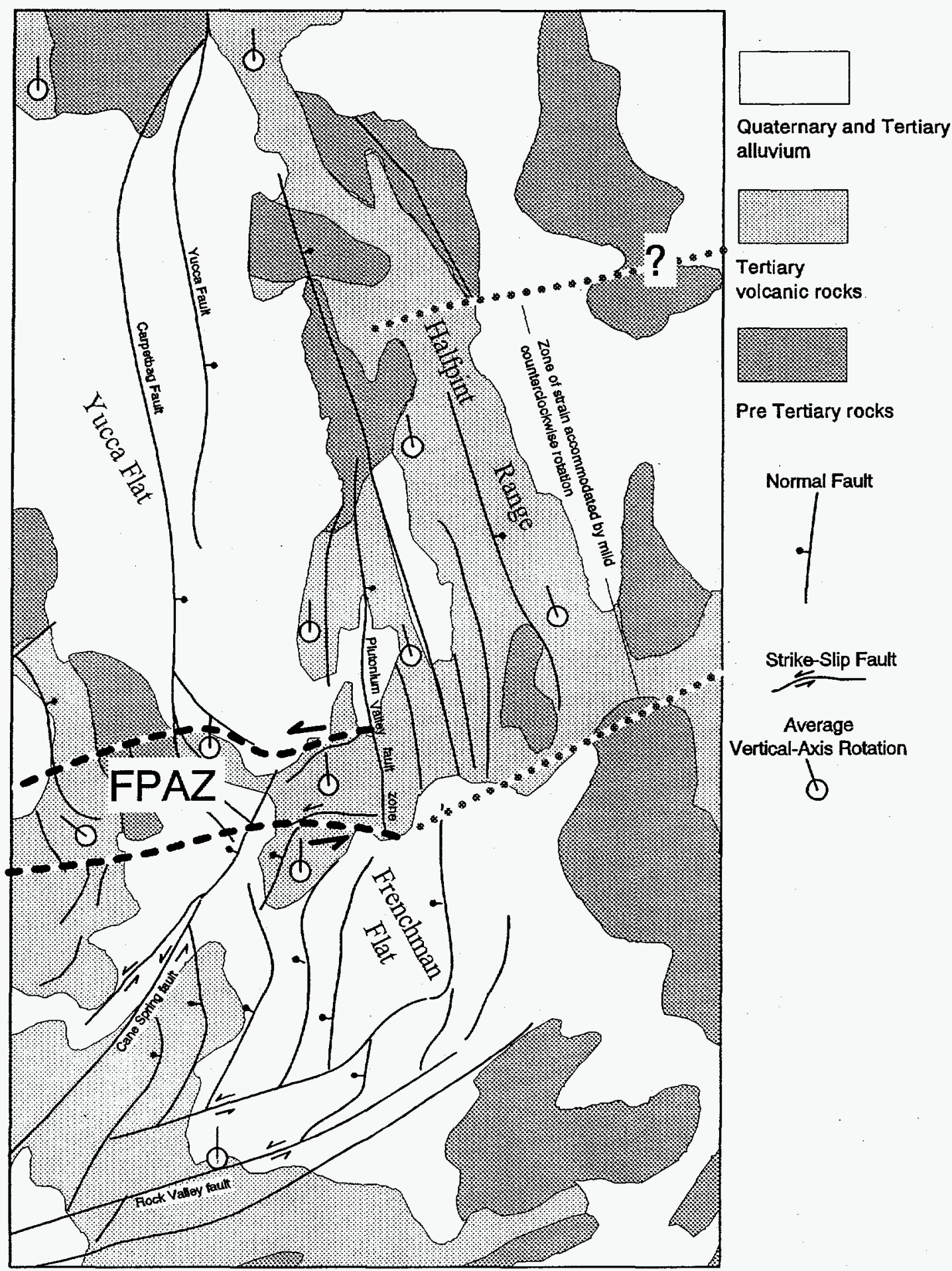

Figure 8. Tectonic interpretation of principal structural features in and near the FPAZ. Location of major faults in the Frenchman Flat area based on interpretation of gravity and aeromagnetic data (Grauch and Hudson, unpub. data). 
Like the FPAZ, many accommodations are also characterized by abundant splaying among faults (e.g., Stock and Hodges, 1990) that commonly have oblique slip (Chorowitz, 1989).

Although early models portrayed transversely oriented accommodation zones as subvertical faults having strike-slip motion that bounded semirigid blocks of contrasting structural polarity (Chapin and others, 1978), more recent detailed studies have shown that most accommodation zones are composed of interfingering normal faults in which the intervening rock twists between opposing dip domains (Colleta and others, 1988; Faulds and others, 1990; Moustafa, 1996). As a consequence, strain transfer is localized between adjacent normal faults and there is little overall strike-slip offset across the zone. Dips of strata typically decrease within this type of accommodation zone relative to adjoining normal fault domains. In contrast to this type of accommodation zone, for at least the Puddle Peak segment there does appear to be consistent sinistral strike-slip offset across the FPAZ. Furthermore, although stratal dips change direction within the FPAZ, they do not notably decrease in amount. These characteristics suggest that the FPAZ is a hybrid between the typical accommodation zone just described and transfer zones. The Embudo zone in the Rio Grande rift (Muehlberger, 1979) and the Morgan zone in the Gulf of Suez (Moustafa, 1996) are other examples of accommodation zones with this mixed type of behavior (Faulds and Varga, in press). For the FPAZ this hybrid behavior might partly stem from the fact that it separates the Yucca Flat domain of dominant normal faulting from the Frenchman Flat domain of mixed normal and strike-slip faulting. Most accommodation zones separate dominant normal faulting.

\section{Potential influences on ground-water flow}

Structures within the FPAZ have the potential to influence the hydrogeologic character of this region in several ways. Faults are more closely spaced within the FPAZ than in the adjacent Yucca Flat or Frenchman Flat domains because of the manner in which strain was partitioned among abundant fault splays. This dense spacing of faults almost certainly increased the fracture conductivity of this region relative to the surroundings. Moreover, the transverse orientation of common strike slip fault sets within the FPAZ may foster anisotropic conductivity with potential for lateral redirection of the generally southward flow of ground water through the Yucca Flat basin to the southwest toward the ultimate inferred discharge areas of Ash Meadows.

The high elevation of Miocene volcanic rocks and consequently the underlying Paleozoic rocks within the FPAZ could potentially allow for paths of exchange between different level aquifers (carbonate, welded tuff, and alluvial) through which ground water flows south from Yucca Flat. The regional water table level in southern Yucca Flat generally lies between 2400 and $2500 \mathrm{ft}$ elevation (Doty and Thordarson, 1983; Laczniak and others, 1996). Cross sections through the Puddle Peak segment of the FPAZ (Plate 1) illustrate that Paleozoic rocks of the lower carbonate aquifer form a faulted ridge within the accommodation zone that reach elevations as great as $3500 \mathrm{ft}$ and thus extends well above the water table. Throw on individual faults within the FPAZ, however, are generally insufficient to juxtapose the different aquifer units. 


\section{Acknowledgments}

I thank J.C. Cole, S.A. Minor, and J.E. Faulds for discussions during the course of the study. J.E. Faulds and P.D. Rowley provided helpful manuscript preprints. Computer software of J. Angelier greatly facilitated plotting and interpretation of fault data. B. Dosier made available a highly useful suite of 1:6,000-scale color infra-red aerial photos encompassing the French Peak area. P.D. Rowley improved this report with a fine review.

\section{References}

Anders, M.H., Spiegelman, M., Rodgers, D.W., and Hagstrum, J.T., 1993, The growth of fault-bounded tilt blocks: Tectonics, v. 12, p. 1451-1459.

Angelier, Jacque, 1990, Inversion of field data in fault tectonics to obtain the regional stress, III, A new rapid direct inversion method by analytical means: Geophysical Journal International, v. 103, p. 363-376.

Borradaile, G.J., 1981, Particulate flow of rock and the formation of cleavage: Tectonophysics, v. 72 , p. 305-321.

Bosworth, W., 1985, Geometry of propagation continental rifts: Nature, v. 316, p. 625 627.

Buck, W.R., 1988, Flexural rotation of normal faults: Tectonics, v. 7, p. 959-973.

Byers, F.M., Jr., Carr, W.J., and Orkild, P.P, 1989, Volcanic centers of southwestern Nevada: Evolution of understanding, 1960-1988: Journal of Geophysical Research, v. 94, p. 5908-5924.

Carr, W.J., 1974, Summary of tectonic and structural evidence for stress orientation at the Nevada Test Site: U.S. Geological Survey Open-File Report 74-176, 53 p.

Carr, W.J., 1984, Regional structural setting of Yucca Mountain, southwestern Nevada, and late Cenozoic rates of tectonic activity in part of the southwestern Great Basin, Nevada and California: U.S. Geological Survey Open-File Report 84-854, $109 \mathrm{p}$.

Chapin, C.E., Chamberlin, R.M., Osburn, G.R., White, D.L., and Sanford, A.R., 1978, Exploration framework of the Socorro geothermal area: in $\mathrm{F}$

Chorowicz, J., 1989, Transfer and transform fault zones in continental rifts: Examples in the Afro-African rift system. Implications of crust breaking: Journal of African Earth Sciences, v. 8, p. 203-214.

Colleta, B., Le Quellec, P., Letouzey, J., and Moretti, I., 1988, Longitudinal evolution of the Suez rift structure (Egypt): Tectonophysics, v. 153, p. 221-233. 
Davis, G.A., and Burchfiel, B.C., 1973, Garlock fault: An intra-continental transform structure, southern California: Geological Society of America Bulletin, v. 84, p. 1407-1422.

Doty, D.G., and Thordarson, William, 1983, Water table in rocks of Cenozoic and Paleozoic age, 1980, Yucca Flat, Nevada Test Site, Nevada: U.S. Geological Survey Water-Resources Investigations Report 83-4067, 1 sheet, scale 1:48,000.

Drellack, S.L., Jr., Prothro, L.B., McCall, R.L, and Thompson, P.H., 1992, Preliminary geology and drill hole data report from groundwater characterization well ER-6-1, Nevada Test Site, Nye County, Nevada: Raytheon Services Nevada report, 103 pp.

Faulds, J.E., Geissman, J.W., and Mawer, C.K, 1990, Structural development of a major extensional accommodation zone in the Basin and Range province, northeastern Arizona and southern Nevada: Implications for kinematic models of continental extension, in Wernicke, B.P., ed., Basin and Range extensional tectonics near the latitude of Las Vegas, Nevada: Geological Society of America Memoir 176, p. 3776.

Faulds, J.E., and Varga, R.J., in press, The role of accommodation zones and transfer zones in the regional segmentation of extended terranes: in Faulds, J.E., and Stewart, J.H., eds., Accommodation zones and transfer zones: The regional segmentation of the Basin and Range, Geological Society of America Special Paper 323.

Fonseca, Julia, 1988, The Sou Hills: A barrier to faulting in the central Nevada seismic belt: Journal of Geophysical Research, v. 93, p. 475-489.

Hinrichs, E.N., and McKay, E.J., 1965, Geologic map of the Plutonium Valley quadrangle, Nye and Lincoln Counties, Nevada: U.S. Geological Survey Geologic Quadrangle Map GQ-384, 1:24,000.

Hudson, M.R., 1992, Paleomagnetic data bearing on the origin of arcuate structures in the French Peak-Massachusetts Mountain area of southern Nevada: Geological Society of America Bulletin, v. 104, 581-594.

Hudson, M.R., Sawyer, D.A., and Warren, R.G., 1994, Paleomagnetism and rotation constraints for the middle Miocene southwestern Nevada volcanic field: Tectonics, v. 13, p. $258-277$.

Hudson, M.R, Rosenbaum, J.G., Gromme, C.S., Scott, R.B., and Rowley, P.D., in press, Paleomagnetic evidence for counterclockwise rotation in a broad sinistral shear zone, Basin and Range province, southeastern Nevada and southwestern Utah: in Faulds, J.E., and Stewart, J.H., eds., Accommodation zones and transfer zones: The regional segmentation of the Basin and Range, Geological Society of America Special Paper 323. 
Laczniak, R., Cole, J.C., Sawyer, D.A., and Trudeau, D.A., 1996, Summary of hydrogeologic controls on ground-water flow at the Nevada Test Site, Nye County, Nevada: U.S. Geological Survey Water-Resource Investigations Report 96-4109, $59 \mathrm{p}$.

McKeown, F.A., Healey, D.L., and C.H. Miller, 1976, Geologic map of the Yucca Lake quadrangle, Nye County, Nevada: U.S. Geological Survey Geologic Quadrangle Map GQ-1327, scale 1:24,000.

Minor, S.A., 1995, Superposed local and regional paleostresses: Fault-slip analysis of Neogene extensional faulting near coeval caldera complexes, Yucca Flat, Nevada: Journal of Geophysical Research, v. 100, p. 10507-10528.

Minor, S.A., Hudson, M.R, and Fridrich, C.F., 1997, Fault-slip and paleomagnetic data, paleostress analysis, and preliminary interpretations bearing on the Neogene tectonic evolution of northern Crater Flat basin, Nevada: U.S. Geological Survey Open-File Report 97-285, 98 p.

Morley, C.K., Nelson, R.A., Patton, T.L., and Munn, S.G., 1990, Transfer zones in the East African Rift system and their relevance to hydrocarbon exploration in rifts: American Association of Petroleum Geologists Bulletin, v. 74, p. 1234-1253.

Moustafa, A.R, 1996, Internal structure and deformation of an accommodation zone in the northern part of the Suez rift: Journal of Structural Geology, v. 18, p. 93-107.

Muehlberger, W.R., 1979, The Embudo fault between Pilar and Arroyo Hondo, New Mexico: An active intracontinental transform fault: New Mexico Geological Society Guidebook 30, p. 77-82.

Nelson, M.R., and Jones, C.H., 1987, Paleomagnetism and crustal rotation along a shear zone, Las Vegas Range, southern Nevada: Tectonics, v. 6, p. 13-33.

Nelson, R.A., Patton, T.L., and Morley, C.K., 1992, Rift-segment interaction and its relation to hydrocarbon exploration in continental rift systems: American Association of Petroleum Geologists Bulletin, v. 76, p. 1153-1169.

Petit, J.P., 1987, Criteria for the sense of movement on fault surfaces in brittle rocks: Journal of Structural Geology, v. 9., p. 597-608.

Rosenbaum, J.G., Hudson, M.R., and Scott, R.B., 1991, Paleomagnetic constraints on the geometry and timing of deformation of Yucca Mountain, Nevada: Journal of Geophysical Research, v. 96, p. 1963-1979.

Rowley, P.D., in press, Cenozoic transverse zones and igneous belts in the Great Basin, western United States, and their tectonic and economic implications: Faulds, J.E., and Stewart, J.H., eds., Accommodation zones and transfer zones: The regional 
segmentation of the Basin and Range, Geological Society of America Special Paper 323.

Sawyer, D.A., Fleck, R.J., Lanphere, M.A., Warren, R. G., Broxton, D.E., and Hudson, M.R, 1994, Episodic caldera volcanism in the Miocene southwestern Nevada volcanic field: Revised stratigraphic framework, ${ }^{40} \mathrm{Ar} /{ }^{39} \mathrm{Ar}$ geochronology, and implications for magmatism and extension: Geological Society of America Bulletin, v. 106, p. 1304-1318.

Scott, R.B, 1990, Tectonic setting of Yucca Mountain, southwest Nevada, in Wernicke, B.P., ed., Basin and Range extensional tectonics near the latitude of Las Vegas, Nevada: Geological Society of America Memoir 176, p. 251-282.

Sengor, A.M.C., 1987, Cross-faults and differential stretching of hinging walls in regions of low-angle normal faulting: Examples from western Turkey: in Coward, M.P., Dewey, J.F., and Hancock, P.L., eds., Continental extensional tectonics, Geological Society of London Special Publication 28, p 575-589.

Sibson, R.H., 1977, Fault rocks and fault mechanisms: Journal of the Geological Society of London, v. 2., 165-171.

Stewart, J.H., 1980, Regional tilt patterns of late Cenozoic basin-range fault blocks, western United States: Geological Society of America Bulletin, v. 91, p. 460-464.

Stock, J.M., and Hodges, K.V., 1990, Miocene to Recent structural development of an extensional accommodation zone, northeastern Baja California, Mexico: Journal of Structural Geology, v. 12, p. 315-328.

Warren, R.G., Sawyer, D.A., and Covington, H.R., 1989, Revised volcanic stratigraphy of the southwestern Nevada volcanic field, Proceedings, Fifth Symposium on Containment of Underground Nuclear Explosions, Santa Barbara, California, September 18-22, 1989, Lawrence Livermore National Laboratory Publication, p. 387.

Wernicke, B.P., and Burchfiel, B.C., 1982, Modes of extensional tectonics: Journal of Structural Geology, v. 4, p. 105-115.

Withjack, M.O., Olsen, John, and Peterson, Eric, 1990, Experimental models of extensional forced folds: American Association of Petroleum Geologists Bulletin, v. 74, p. $1038-1054$. 
Appendix A

\section{Description of map units for geologic map of the southwestern quarter of the Plutonium Valley Quadrangle}

QTa Undivided alluvium and colluvium (Quaternary and Pliocene?)-- Angular, locally derived gravel and well rounded, reworked gravel mostly on dissected fans and pediments

Tma Ammonia Tanks Tuff, Timber Mountain Group (Miocene) -- Calc-alkaline welded ash-flow tuff erupted at $11.45 \mathrm{Ma}$ from Ammonia Tanks caldera of the Timber Mountain caldera complex. Compositionally zoned from lower, volumetrically dominant rhyolite (sanidine, quartz, plagioclase, and sparse biotite, clinopyroxene, sphene) to upper crystal-rich trachyte (sanidine, biotite, plagioclase, quartz, and sparse sphene, clinopyroxene). Orangish-tan poorly welded basal tuff is overlain by light-gray to chocolate-brown, partially to densely welded tuff. Thin bedded-tuff zone locally present at base. Normal remanent magnetization. Thickness about 50-120 m

Tmr Rainier Mesa Tuff, Timber Mountain Group (Miocene) -- Calc-alkaline welded ash-flow tuff erupted at $11.6 \mathrm{Ma}$ from Rainier Mesa caldera of the Timber Mountain caldera complex. Compositionally zoned from lower, volumetrically dominant rhyolite (sanidine, quartz, and sparse plagioclase, biotite) to upper crystal-rich trachyte (biotite, sanidine, plagioclase, quartz, and sparse clinopyroxene). Basal pink poorly welded zone overlain by white to light gray partially welded zone overlain by medial purplish gray densely welded zone. Partially welded upper part of the tuff is whitish gray but weathers to brown in capping, ledge-forming, vapor phase zone. Reverse remanent magnetization. Thickness 110-150 m

Tmra pre-Rainier Mesa tuff (Miocene) -- Nonwelded yellowish white tuff beds. Contains quartz, sanidine, and sparse plagioclase and biotite. Thickness $0-80 \mathrm{~m}$

Tpt Topopah Spring Tuff, Paintbrush Group (Miocene) -- Calc-alkaline welded ashflow tuff erupted at $12.8 \mathrm{Ma}$. Compositionally zoned from lower crystal-poor rhyolite (sanidine, plagioclase, sphene) to upper crystal-rich trachyte (sanidine, plagioclase, biotite, clinopyroxene, sphene). Lower tan poorly welded zone grades into orange-brown, platy weathering, densely welded crystal-poor zone. The crystal-poor zone passes upward into purplish-red, upper, crystal-rich part that contains zones of lithophysae and is commonly capped by black vitrophyre and variably preserved poorly welded brown tuff. Normal remanent magnetization. Thickness $0-90 \mathrm{~m}$

Tc Calico Hills Formation (Miocene) -- Nonwelded bedded tuff associated with lava eruptions in the Pahute Mesa area to the northwest (Warren and others, 1989). Deposits are white-weathering bedded tuff. Contains quartz, sanidine, plagioclase, and biotite along with red lithic fragments. Included in Tcw on cross sections. Thickness $0-2 \mathrm{~m}$ 
Tcw Undivided non-welded massive to bedded tuffs of the Calico Hills and Wahmonie Formations (Miocene) -- Equivalent to tuff and tuffaceous rocks of Mount Salyer and Survey Butte(?) Member of the Piapi Canyon Formation of Hinrich and McKay (1965)

Tw, Twb Wahmonie Formation (Miocene) -- Dacite lava flow and associated nonwelded tuff deposits enupted at 12.9 Ma. Contains abundant plagioclase, hornblende, and biotite. Tw is a lava flow restricted to southern part of area, where it overlies Twb, which consists of bedded, biotite-rich tuffs. Lava flow formed paleotopographic high that younger $\mathrm{Tc}, \mathrm{Tpt}$, and Tmra units pinch out against. In northern areas Twb composed of tuff locally interbedded with red volcanogenic sandstone in basal parts of the sequence. Twb included in Tcw on cross sections. Thickness 80 to $>140 \mathrm{~m}$, thinning northward

Tcbs Bullfrog Tuff, Stockade Wash lobe, Crater Flat Group (Miocene) -- Poorly welded ash-flow tuff erupted at 13.25 Ma identified on northeastern edge of area by Hinrichs and McKay (1965). Normal remanent magnetization. Thickness 0-30 m

$\mathrm{Tu} \quad$ Undivided mostly non-welded ash-flows tuffs and bedded tuffs (Miocene) -Composed principally of Crater Flat Group but may also contain older units such as the Grouse Canyon Tuff, tuff of Yucca Flat, or Redrock Valley Tuff. Equivalent to Tuff of Pavits Spring of Hinrich and McKay (1965). Thickness poorly constrained but about $245 \mathrm{~m}$ in drill hole ER-6-1 (Drellack and others, 1992) directly north of map area 
Correlation of Map Units

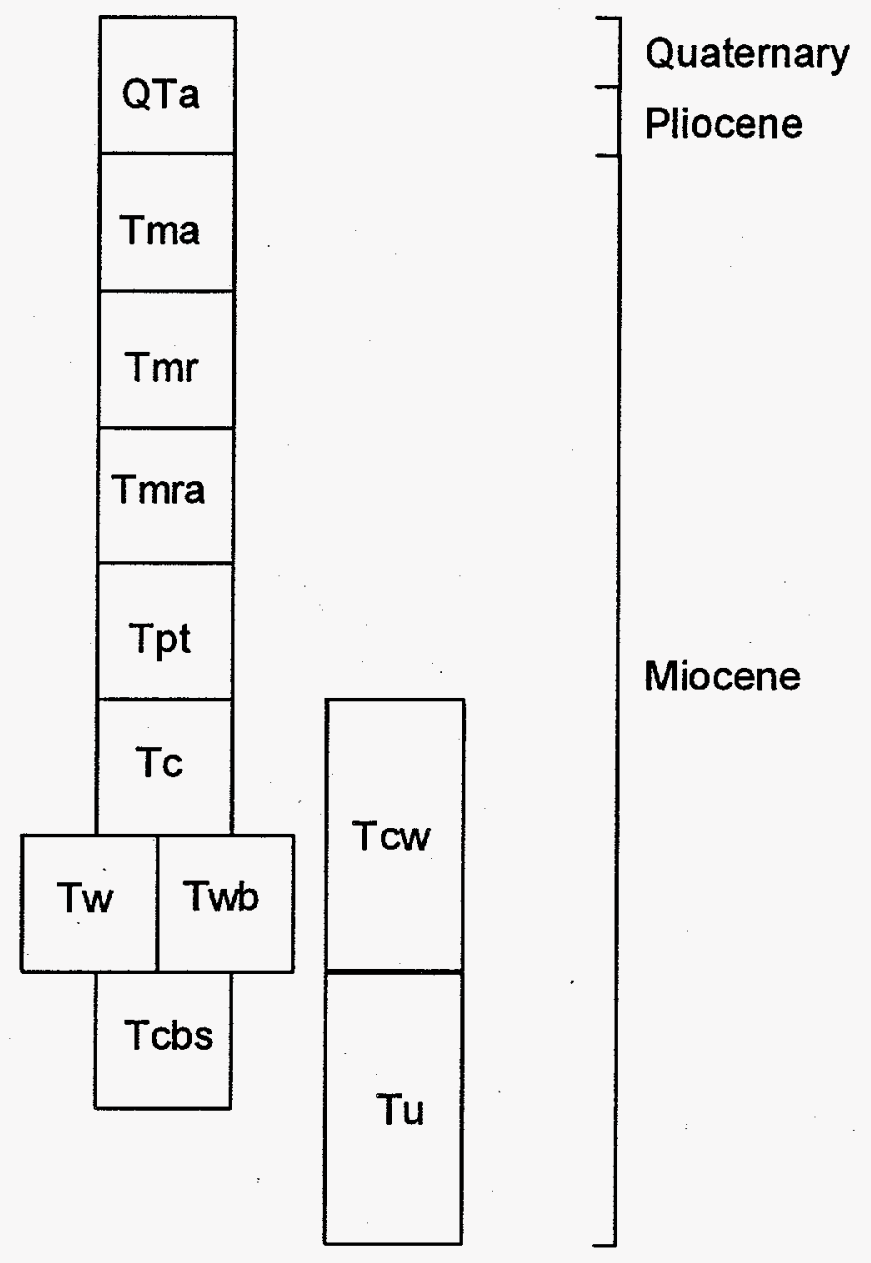

\section{Explanation}

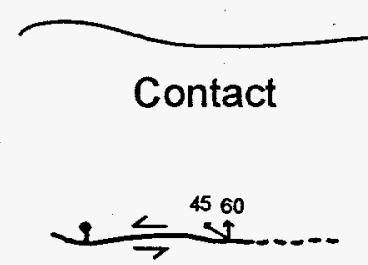

Fault, with fault dip and rake of striation dashed were concealed, bar and ball on downthrown side, arrows show sense of lateral offset

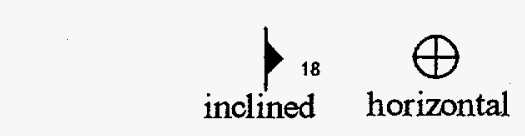

Strike and dip of compaction foliation<smiles>[Te][Te][Te]</smiles>

Strike and dip of bedding 
Page(s) size did not permit electronic reproduction. Information may be purchased by the general public from the National Technical Information Service, U.S. Department of Commerce, Springfield, VA 22161 (Area Code 703-487-4650). DOE and DOE contractors may purchase information by contacting DOE's Office of Scientific and Technical Information, P.O. Box 62, Oak Ridge, TN 37831, Attn: Information Services (Area Code 423-576-8401). 